\title{
KOMPETENSI DIAKEN BERDASARKAN 1 TIMOTIUS 3:8-13
}

\author{
Ezra Tari \\ (Dosen Institut Agama Kristen Negeri Kupang: tariezra@gmail.com)
}

\begin{abstract}
The competence of a deacon in 1 Timothy 3: 8-13 are the requirements that should get the attention of the church. In this article, the author describes the duties and responsibilities of a deacon. The purpose of this study is that the deacons will understand their duties and responsibilities. The author intends to reposition deacons who serve the marginalized. The research method used is hermeneutic. There are four results in this study. First is being able to resist temptation. Second is flawless. Third is trustworthiness.

Fourth is being role models for family members.
\end{abstract}

Key Word: Competencies, Deacons, Serving, 1 Timothy 3: 8-13

\section{A. PENDAHULUAN}

Pekerjaan diaken disebut sebagai pelayanan dari kasih atau kemurahan kristiani karena memperlihatkan kasih Allah dalam Kristus, mengurus dan membagi-bagikan persembahan jemaat, dan menyadarkan jemaat. ${ }^{1}$ Diaken dapat melakukan tugas mulai dari menata bunga, memimpin aksi politik, memberi makan orang-orang miskin, mengelola makan malam, membagikan buletin gereja, dan berbagi dalam tanggung jawab pastoral gereja. ${ }^{2}$ Diaken dianggap hanya sebatas memungut kolekte dan melayani meja perjamuan. A.A. Van Ruler dalam bukunya yang berjudul "Mengapa Saya Harus Ke Gereja?" yang dikutip Noordegraaf mengatakan bahwa fungsi diaken ada dalam empat hal yakni pertama, pemadatan atau berkaitan dengan pelayanan Tuhan. Kedua, latihan yaitu perjalanan hidup dalam melayani Allah. Ketiga, paradigma di mana orang percaya berkumpul untuk memuji Tuhan. Keempat, titik tolak artinya ibadah adalah keseharian hidup. ${ }^{3}$

Diaken, dalam bahasa Yunani diakonos digunakan untuk menjelaskan mengenai orang yang diutus, pelayan, orang yang mengurus pekerjaan rumah, salah satunya memasak makanan. Kata ini dipakai dalam Perjanjian Baru memiliki maksud: (a) makna digunakan untuk seorang bawahan (Mat. 22:13) atau hamba dari sesamanya (Mrk. 9:35; 10:43; Mat 20:26), (b) makna yang sempit digunakan untuk masyarakat Kristen sebagai pelayan Kristus (Yoh 12:26; 2 Kor. 11:23) atau hamba Tuhan (2 Kor 6:3). Selanjutnya, istilah ini digunakan untuk menerangkan tugas penatalayanan bagi umat. ${ }^{4}$ 2010), 64.

${ }^{1}$ J.L.Ch Abineno, Diaken Diakonia Dan Diakonat Gereja (Jakarta: BPK Gunung Mulia,

${ }^{2}$ Alexander Strauch, Paul"s Vision for the Deacons: Assisting the Elders with the Care of God's Church (United Sates of America: Lewis \& Roth Publishers, 2017), 15.

${ }^{3}$ A. Noordegraaf, Orientasi Diakonia Gereja: Teologi Dalam Perspektif Reformasi (Jakarta: BPK Gunung Mulia, 2004), 146.

${ }^{4}$ Alkitab Sabda, "Diaken," Sabda, last modified 2019, accessed May 14, 2020, https://alkitab.sabda.org/dictionary.php?word=Diaken. 
Diaken biasanya berjalan berkeliling mengumpulkan korban jemaat di dalam pinggan, mengail dengan saku-saku yang bertangkai panjang tidak baik dan tidak ada guna. ${ }^{5}$

Dari penjelasan di atas, gereja perlu memberikan perhatian yang serius terhadap kompetensi dari setiap calon diaken karena apabila terpilih, mereka akan menjadi bagian dari pemimpin gereja. Dalam proses pengelolaan gereja, orang yang terpilih sebagai diaken berperan aktif dengan memberikan ide, konsep pemikiran atau pendapat. ${ }^{6}$ Gereja harus menerapkan penatalayanan yang konsisten. Namun, di sisi lain gereja perlu mengetahui rancangan yang cocok untuk dapat disesuaikan dengan keperluan jemaat yang berubah sesuai tuntutan zaman. ${ }^{7}$ Di GBKP (Gereja Batak Karo Protestan) dan di GKPS (Gereja Kristen Prostestan Simalungun), diaken disebut dengan Syamas. Namun pada prakteknya, Syamas ini berbeda dengan diaken yang disebut dalam Perjanjian Baru karena Syamas merupakan jabatan wajib sebelum menjadi penatua. Hal itu berarti diaken dilihat sebagai sebuah jabatan bertingkat dalam gereja. ${ }^{8}$

Selanjutnya ada gereja yang menerapkan dua bentuk jabatan gerejawi yakni pelayanan dan keorganisasian. Tugas penatalayanan dilakukan oleh pendeta, penatua, diaken, dan guru. Sedangkan, fungsi keorganisasian mencakup badan pelayanan, pembantu pelayanan, dan unit pembantu pelayanan. Para pelayan diberi kelengkapan supaya bisa melaksanakan tugas dengan mahir. ${ }^{9}$ Ada dugaan bahwa garis penugasan yang belum jelas antara penatua dan diaken, sehingga diaken melaksanakan tugas-tugas penatua seperti memimpin ibadah, bahkan diaken masih dianggap sebagai pembantu penatua. ${ }^{10}$ Pemahaman mengenai kompetensi diaken memiliki implikasi praktis dan penting. ${ }^{11}$ Lebih lanjut, ada banyak orang yang mengklaim dirinya pelayan Tuhan dan diangkat gereja sebagai diaken, namun bersikap memimpin dengan tangan besi, arogan, terlibat dalam dosa

${ }^{5}$ J.L.Ch Abineno, Unsur-Unsur Liturgi Yang Dipakai Oleh Gereja Di Indonesia (Jakarta: BPK Gunung Mulia, 2007), 101.

${ }^{6}$ Suharto Prodjowijono, Manajemen Gereja: Sebuah Alternatif (Jakarta: BPK Gunung Mulia, 2008), 10.

${ }^{7}$ Mariani Febriana, "Pietas Dan Caritas: Pelayanan Diakonia Sebagai Suatu Implementasi Kepedulian Sosial Gereja Untuk Menolong Meretas Angka Kemiskinan Di Indonesia," Jurnal Theologi Aletheia 16, no. 7 (2014): 45-69.

${ }^{8}$ Jonathan Freshly Sembiring, "Gereja Dan Diakonia," Jurnal Teologi Pondok Daud 6, no. 1 (March 3, 2020): 35-42, accessed November 24, 2020, http://ejournal.sttpkmedan.ac.id/index.php/pondokdaud/article/view/7.

${ }^{9}$ Majelis Sinode GMIT, "Peraturan Pemilihan Penatua, Diaken, Pengajar Dan Pengesahan Anggota Majelis Jemaat," Sinode GMIT, last modified February 2018, accessed May 16, 2020 , https://sinodegmit.or.id.

${ }^{10}$ Sinode GMIT, "Diaken Masih Belum Melaksanakan Tugasnya," Sinode GMIT, last modified December 2016, accessed May 14, 2020, https://sinodegmit.or.id/diaken-masih-belummelaksanakan-tugasnya-ss-gmit-xxxiii/.

${ }^{11}$ Joseph Ferrari and Danielle Vaclavik, "The Leadership Style of Permanent Deacons: Servant and Transformational Middle-Aged Ministers," North American Journal of Psychology 18 (2016): 1-16. 
perzinahan, bahkan sampai melakukan dosa perselingkuhan. ${ }^{12}$ Berdasarkan pemikiran yang telah penulis paparkan, fokus kajian ini adalah kualifikasi diaken berdasarkan 1 Timotius 3:8-13. Kajian ini bertujuan untuk menggali ulang kualifikasi, tujuan dan fungsi diaken dalam pelayanan gereja.

\section{B. METODOLOGI}

Metode penelitian yang digunakan adalah hermeneutik. Langkah-langkah hermeneutika adalah menetapkan teks yang hendak diketahui maknanya, memahami lingkungan tempat teks itu berasal, memahami makna bagi pembuatnya dengan berdialog berulang-ulang, dan menerapkan makna pada masalah masa kini. ${ }^{13}$ Hermeneutika merupakan representasi simbolis dari makna penulis. Artinya, bahasa mengungkapkan, tetapi bukan merupakan makna seorang penulis, serta sejarah atau situasi budaya. ${ }^{14}$ Langkah hermeneutik yang dilakukan penulis yakni, menetapkan teks yang akan diselidiki yaitu 1 Timotius 3: 8-13, selanjutnya berusaha menafsirkan dengan mengikut pola teks dan konteks sehingga mendapatkan hakikat utama dari teks tersebut. ${ }^{15}$ Penulis menggunakan analisis teks untuk menelusuri teks yang dipilih. Analisis teks menurut Roland Barthes, akan menghasilkan makna denotatif yakni arti eksplisit dan makna konotatif yaitu arti implisit. ${ }^{16}$ Analisis teks juga menggunakan metode kritik teks sesuai dengan syarat-syarat atau alasan-alasan yang meyakinkan. ${ }^{17}$

\section{PEMBAHASAN}

1. Analisis Teks

Ayat 8: Paulus mengubah kualifkasi seorang episkopos, pengawas, menggunakan kata houtos, yang berarti bijaksana atau dengan cara yang sama. ${ }^{18} \mathrm{Hal}$ ini berarti diaken tidak boleh mengatakan hal yang tidak sama pada kumpulan yang tidak selaras supaya diterima menggunakan alasan-alasan yang keliru. Hal tersebut merupakan suatu bentuk kebohongan serta kepalsuan. Frasa tidak boleh tamak (seorang yang menggemari untung yang belum bersih) mengacu pada sifat jujur

${ }^{12}$ Dessy Handayani, “Isu-Isu Kontemporer Dalam Jabatan Gerejawi,” Kurios 3, no. 1 (February 11, 2018): 66, accessed November 24, 2020, http://www.sttpb.ac.id/ejournal/index.php/kurios.

${ }^{13}$ Deora Westa Purba, "Hermeneutika Sebagai Metode Pendekatan Dalam Teologi," Regula Fidei 3, no. 1 (March 2018): 520-530, accessed November 12, 2020, http://ejournal.uki.ac.id/index.php/regulafidei/article/view/978.

${ }^{14} \mathrm{C}$. Bingham, "Hermeneutics," International Encyclopedia of Education (Third Edition) (Elsevier, 2010), https://www.sciencedirect.com/science/article/pii/B9780080448947005595.

${ }^{15}$ R. Masri Sareb Putra, "Tradisi Hermeneutika Dan Penerapannya Dalam Studi Komunikasi," Jurnal ULTIMA Comm 4, no. 1 (June 1, 2012): 73-85, accessed November 13, 2020, http://ejournals.umn.ac.id/index.php/FIKOM/article/view/431.

${ }^{16}$ Yasraf Amir Piliang, "Semiotika Teks: Sebuah Pendekatan Analisis Teks," MediaTor 5, no. 2 (2004): 189.

${ }^{17}$ A.A Ulrich Beyer Sitompul, Metode Penafsiran Alkitab (Jakarta: BPK Gunung Mulia, 2009), 37.

${ }^{18}$ Charles R. Swindoll, Swindoll's Living Insights New Testament Commentary; Volume 11 (United States of America: Zondervan, 2019), 232. 
dalam berbisnis para pemimpin gereja yang memiliki pekerjaan lebih dari satu. ${ }^{19} \mathrm{R}$. Budiman menjelaskan kalimat haruslah orang terhormat artinya tidak memberi sandungan, melainkan terpandang di lingkungannya. Seorang diaken mampu memimpin keluarganya sendiri dan mampu menyelesaikan persoalan-persoalan yang dihadapi. Ia memberi dampak sosial yang baik. ${ }^{20}$ Diaken memiliki perkataan yang konsisten dari satu orang ke orang yang lain. ${ }^{21}$ Diaken yang memenuhi syarat tahu menjaga rahasia (Ams. 11:13). Mereka memiliki kehidupan yang terintegrasi, jadi diaken berperilaku sama selama seminggu seperti yang mereka lakukan di gereja. ${ }^{22}$ Tugas diaken dapat mencakup bidang pelayanan apapun kecuali kepemimpinan rohani gereja yang merupakan tanggung jawab penatua. ${ }^{23}$

Selanjutnya, diaken tidak menceritakan rahasia seseorang kepada orang lain (gosip). Diaken bukan penggemar anggur di mana dosa ini telah disinggung dalam ayat 3, yakni suka mabukmabukan. Diaken juga tidak boleh serakah, artinya selalu ingin beroleh banyak untuk diri sendiri. Kata ini memiliki makna yang lebih keras dibanding ayat 3 (hamba uang) karena diaken langsung bersentuhan dengan uang. Larangan ini menggarisbawahi perlunya kesetiaan dan kejujuran dalam menangani masalah keuangan gereja. ${ }^{24}$ Sehingga, diaken harus kuat terhadap godaan penyalahgunaan jabatan yang suci untuk memperoleh keuntungan. ${ }^{25}$ Diaken juga seharusnya menentang penggunaan anggur yang berlebihan, yang menyebabkan mabuk dan mendiskualifikasi seseorang dari pekerjaan ini. ${ }^{26}$ Secara praktis, gereja tidak boleh menugaskan seorang yang minum terlalu banyak untuk menjadi diaken. ${ }^{27}$ Pada saat pemilihan diaken, syarat tersebut harus menjadi perhatian sehingga diaken mampu bertahan terhadap godaan yang telah dijelaskan di atas.

Ayat 9: merawat hal yang tersembunyi nampaknya merujuk pada orang Yahudi dan Yunani yang masuk dalam keluarga Allah (lih Ef. 2:11-3:13; Kol. 1: 26, 27) ${ }^{28}$ Rahasia iman adalah isi iman yang kaya telah berabad-abad dirahasiakan oleh Allah tetapi pemberitaan Injil dinyatakan kepada orang percaya. Kekayaan itu dipelihara dalam kehidupan orang percaya, jika hatinya suci artinya hidup etisnya baik. ${ }^{29}$ Kata hati nurani menggambarkan kehidupan dan perkataan diaken yang berpadanan dengan Injil (1 Tim. 1: 5). Diaken berpegang teguh pada iman dengan hati nurani yang

${ }^{19}$ Utley, Perjalanan Penginjilan Paulus Ke-4: I Timotius, Titus Dan II Timotius, 37.

${ }^{20}$ Budiman, Tafsiran Alkitab: Surat-Surat Pastoral I \& II Timotius Dan Titus, 30.

${ }^{21}$ Zehr, Believers Church Bible Commentary: 1 \& 2 Timothy, Titus, 82.

${ }^{22}$ Swindoll, Swindoll's Living Insights New Testament Commentary; Volume 11, 65.

${ }^{23}$ Ronald W. Leigh, Melayani Dengan Efektif: 34 Prinsip Pelayanan Bagi Pendeta Dan Kaum Awam (Jakarta: BPK Gunung Mulia, 2007), 225.

${ }^{24}$ Zehr, Believers Church Bible Commentary: $1 \& 2$ Timothy, Titus, 83.

${ }^{25}$ Budiman, Tafsiran Alkitab: Surat-Surat Pastoral I \& II Timotius Dan Titus, 30.

${ }^{26}$ Zehr, Believers Church Bible Commentary: 1 \& 2 Timothy, Titus.

${ }^{27}$ Swindoll, Swindoll's Living Insights New Testament Commentary: 1 \& 2 Timoty, Titus.

${ }^{28}$ Utley, Perjalanan Penginjilan Paulus Ke-4: I Timotius, Titus Dan II Timotius, 38.

${ }^{29}$ Budiman, Tafsiran Alkitab: Surat-Surat Pastoral I \& II Timotius Dan Titus. 
dimurnikan oleh Tuhan. Mereka meyakini kejujuran dan integritas penuh yang transparan dan untuk meyakinkan gereja akan kemampuan ini, para diaken harus terlebih dahulu diuji. ${ }^{30}$

Diaken mempunyai tugas untuk memelihara rahasia iman. Kata rahasia yang dikutip oleh Alexander Strauch dalam Expository Dictionary of New Testament adalah misterius, di luar jangkauan pemahaman biasa. Dalam pemahaman sederhana, misteri memiliki arti mengenai penyingkapan kebenaran. ${ }^{31}$ Diaken harus memegang teguh Injil kerajaan Allah secara konsisten menegakkan kebenaran dengan melayani. Ia mengusahakan ketulusan, kemurnian, dan tunduk pada kebenaran Alkitab.

Ayat 10: Mereka sebaiknya diuji untuk diketahui kualitasnya. Kata tersebut memiliki tense present passive imperative. Kata Yunani dokimazō, dipakai dengan dengan makna mendapat kesepakatan (lih Rm. 2:18; 12:2; 14:22; 1 Kor. 3:13). Hal ini bertentangan dengan kata peirazō, yang berarti menguji dengan pemikiran terhadap kehancuran (lih 1 Kor. 2:5; 10:9, 13; Gal. 6:1; Flp. 1:10; 1 Tes. 3:5). ${ }^{32}$ Seorang pejabat gereja hendaknya telah diuji lebih dahulu untuk mengenal kelakuannya, baik di dalam jemaat maupun di tengah-tengah masyarakat. Nasihat ini telah disampaikan dalam ayat 6, 7: Dia tidak boleh menjadi orang yang baru bertobat atau dia mungkin menjadi sombong dan jatuh dosa. Dia harus dikenal baik oleh orang-orang di luar iman, agar dia tidak jatuh dalam kehinaan dan terperangkap dalam perangkap iblis. Oleh sebab itu penting bagi diaken untuk memiliki kehidupan yang dipimpin oleh Roh Kudus, sehingga iman itu terpancar dari kualitas moral yang dapa dilihat oleh orang di luar gereja. ${ }^{33}$

Para diaken harus terlebih dahulu diuji, sebelum mereka melayani. Meskipun orang tidak dapat memastikan, ini juga dapat dianggap benar oleh para pengawas. Ada "alsd 'di awal kalimat Paulus, yang tidak diterjemahkan dalam NIV, yang mungkin merujuk kembali kepada para pengawas (d. NEB," tidak kurang dari para uskup "). Akan tetapi, mungkin, dengan sedikit merujuk pada ayat 9; adalah mereka juga harus diuji, untuk melihat apakah mereka berpegang teguh pada iman. ${ }^{34}$ Diaken haruslah orang-orang yang telah diamati selama periode waktu tertentu untuk melihat bagaimana mereka menanggapi kesulitan. ${ }^{35}$

Ayat 11: istri sangat perlu memiliki sifat yang baik sebagai pendamping yang baik. Para istri ikut merawat rumah tangga ${ }^{36}$ Beberapa orang berpendapat bahwa ayat 11 merujuk pada istri seorang

\footnotetext{
${ }^{30}$ Zehr, Believers Church Bible Commentary: 1 \& 2 Timothy, Titus.

${ }^{31}$ Strauch, Paul"s Vision for the Deacons: Assisting the Elders with the Care of God's Church.

${ }^{32}$ Utley, Perjalanan Penginjilan Paulus Ke-4: I Timotius, Titus Dan II Timotius.

${ }^{33}$ Gidion, Gidion. "Memahami Pekerjaan Roh Kudus dalam Pelayanan Gereja Berdasarkan 1 dan 2 Timotius." HARVESTER: Jurnal Teologi dan Kepemimpinan Kristen 4.2 (2019): 108-121.

${ }^{34} \mathrm{Fee}$, New International Biblical Commentary 1 and 2 Timothy, Titus, 88.

${ }^{35}$ Swindoll, Swindoll's Living Insights New Testament Commentary: 1 \& 2 Timoty, Titus.

${ }^{36}$ Budiman, Tafsiran Alkitab: Surat-Surat Pastoral I \& II Timotius Dan Titus, 31.
} 
diaken, sementara yang lain berpikir Paulus berbicara tentang diaken wanita. ${ }^{37}$ Mereka harus layak dihormati. Lalu ada dua larangan terhadap diaken wanita atau istri diaken yaitu mereka tidak boleh menjadi pembicara jahat (fitnah; lih. Titus 2: 3) dan mampu menahan diri. Akhirnya, mereka harus dapat dipercaya dalam segala hal (setia dalam segala hal; NASB). ${ }^{38}$

Ada tiga hal yang dapat dijelaskan mengenai ayat ini yakni, pertama, ayat tersebut menggambarkan istri para diaken, atau mungkin istri dari semua pejabat gereja. Kedua, ayat ini merujuk pada wanita secara umum. Ketiga, ayat ini membahas tentang wanita yang melayani diaken. ${ }^{39}$ Tanggung jawab seorang diaken tidak lepas dari penggembalaan secara informal. Tentunya Paulus tidak bermaksud menyatakan bahwa seorang diaken tidak boleh mengajar atau memberikan nasehat kepada jemaat. Namun, bagi para diaken, Paulus tidak memberikan daftar tanggung jawab khusus. ${ }^{40}$ Banyak Alkitab terjemahan modern membuat 1 Timotius 3:8-13 menjadi satu paragraf. Diaken-diaken memulai diskusi (lih 1 Tim. 3: 8) dan mengakhiri diskusi (lih 1 Tim 3:13), dan di dalam 1 Tim 3:11 diaken wanita didiskusikan. Inilah sebabnya mengapa beberapa terjemahan menyebut mereka "istri diaken." Namun demikian, penulis berpikir bahwa pembantu diaken, atau diaken wanita, lebih sesuai secara budaya. Pelayan wanita (yaitu, "para janda") secara khusus disebutkan dalam 1 Timotius 5:9$10 .{ }^{41}$

Ayat 12: Dalam ayat ini, Paulus mengulangi apa yang dikatakan di ayat 2 dan 4. Pengawas kemudian harus di atas celaan, suami dari satu istri, sederhana, mengendalikan diri, terhormat, ramah, guru yang cakap (ay. 2). Ia harus mengelola rumah tangganya sendiri dengan baik dan menjaga anakanaknya tetap terkendali tanpa kehilangan martabatnya (ay. 4). Jika memang rumah tangga itu adalah gereja, atau mikrokosmos gereja, bukti bahwa seseorang dapat mengelola gereja dengan baik dapat ditemukan saat seseorang mengelola rumah tangganya. Singkatnya, kualitas yang diperlukan untuk pelayanan di gereja akan terlihat jelas di rumah tangga. ${ }^{42}$ Seorang diaken harus melayani orang-orang di bawah pengawasannya sendiri sebelum berusaha melayani siapa pun di luar rumah. ${ }^{43}$

Ayat 13: Frasa "beroleh kedudukan yang baik" tidak berarti harus merujuk pada posisi kepemimpinan yang lebih tinggi (yaitu pendeta), tapi mungkin kehormatan di dalam komunitas mereka yang memungkinkan mereka untuk dengan berani membagikan Injil. ${ }^{44}$ Kedua pujian ini, tentu saja, justru merupakan kekurangan dari guru-guru palsu. "Ajaran mereka yang sakit" mencakup perilaku yang tidak pantas dan reputasi yang kotor, telah menyebabkan mereka meninggalkan iman

\footnotetext{
${ }^{37}$ Zehr, Believers Church Bible Commentary: 1 \& 2 Timothy, Titus.

${ }^{38}$ Fee, New International Biblical Commentary 1 and 2 Timothy, Titus.

${ }^{39}$ Swindoll, Swindoll's Living Insights New Testament Commentary: 1 \& 2 Timoty, Titus.

${ }^{40}$ Strauch, Paul"s Vision for the Deacons: Assisting the Elders with the Care of God's

Church.

${ }^{41}$ Utley, Perjalanan Penginjilan Paulus Ke-4: I Timotius, Titus Dan II Timotius, 39.

${ }^{42}$ Zehr, Believers Church Bible Commentary: 1 \& 2 Timothy, Titus.

${ }^{43}$ Swindoll, Swindoll's Living Insights New Testament Commentary: 1 \& 2 Timoty, Titus.

${ }^{44}$ Utley, Perjalanan Penginjilan Paulus Ke-4: I Timotius, Titus Dan II Timotius.
} 
yang murni kepada Kristus (1: 5). ${ }^{45}$ Pertama, diaken yang setia menghasilkan dua penghargaan untuk pelayanan kepada yang lain. Kedua, diaken yang setia akan memupuk bukti yang tak tergoyahkan dalam kebenaran Injil. ${ }^{46}$ Secara implisit dalam 1 Tim. 3: 13, diaken mempunyai tugas untuk memberikan kesaksian kepada jemaat bahkan kepada nonkristen. Mereka diharapkan memiliki hasrat untuk terus memperdalam pokok-pokok pengajaran iman Kristen yang dapat dibagikan kepada jemaat. $^{47}$

\section{Aplikasi 1 Timotius 3: 8-13}

Penekanan diaken yang dijelaskan dalam 1 Timotius 3: 8-13 adalah pada karakter dan perilaku. Namun, gereja terlalu sering mengabaikan penekanan ini. Hal yang dipelajari mengenai diaken adalah tanggung jawab pribadi diaken untuk melayani dengan baik. Diaken perlu memiliki karakter dan perilaku yang benar dan dengan demikian, otoritas yang diperoleh seseorang meningkat pengaruh dan reputasi seseorang dalam komunitas yang beriman. Pelayanan yang dilakukan dengan setia dan benar bekerja secara dua arah; yaitu meningkatkan keyakinan seseorang pada identitas dan kemampuannya untuk melayani di komunitas Kristen dan pada saat yang sama, meningkatkan kepercayaan orang lain pada Kristus Yesus. Mengizinkan seseorang yang belum diuji menjadi diaken nantinya dapat menyebabkan banyak masalah.

Tugas-tugas yang dapat dilakukan oleh diaken yaitu bertanggung jawab atas pengelolaan dasar properti gereja. Selain itu, para diaken dapat bertanggung jawab untuk mendistribusikan buletin, mengatur tempat duduk jemaat, atau mempersiapkan elemen-elemen untuk persekutuan. Tugas diaken yang paling direkomendasikan adalah melakukan kebajikan seperti yang tertulis dalam Kis. 6 para diaken harus dilibatkan dalam administrasi dana bagi yang membutuhkan, seperti melayani para kaum miskin dan para janda (bnd. Kis. 6: 1-6 \& Rm. 16: 1-2; Rm.15:25, 26). Paulus tidak memberikan secara rinci tugas diaken, namun dalam surat-suratnya, Paulus memberikan penekanan terhadap pelayanan kasih kepada orang miskin atau kaum marjinal. Diaken tidak hanya menyampaikan pelayanan dengan mengungkapkan sayang pada orang miskin, namun mereka juga bertanggung jawab memelihara misteri iman. Oleh karena itu, mereka wajib belajar menggali firman yang kuasa dan memberitakannya kepada umat atau orang-orang yang dilayani.

\section{KESIMPULAN}

Syarat kompetensi diaken dalam 1 Timotius 3:8-13 sangat jelas sehingga tidak perlu memberi syarat tambahan yang bersifat organisatoris. Jemaat perlu menyadari bahwa diaken bukanlah jabatan organisatoris melainkan pelayanan doa dan kepedulian terhadap sesama yang terpinggirkan.

\footnotetext{
${ }^{45} \mathrm{Fee}$, New International Biblical Commentary 1 and 2 Timothy, Titus.

${ }^{46}$ Swindoll, Swindoll's Living Insights New Testament Commentary: 1 \& 2 Timoty, Titus.

${ }^{47}$ Strauch, Paul"s Vision for the Deacons: Assisting the Elders with the Care of God's
}

Church. 
Penekanan diaken yang dijelaskan dalam 1 Timotius 3: 8-13 adalah pada karakter dan perilaku diaken itu sendiri. Diaken seharusnya memiliki hidup yang selaras dan konsisten dengan perkataannya, menjaga rahasia, tidak mabuk-mabukkan, setia dan jujur dalam hal keuangan, mengelola rumah tangga dengan baik dan memiliki kehidupan yang diuji sebelum menjadi seorang diaken. 


\section{DAFTAR PUSTAKA}

Abineno, J.L.Ch. Diaken Diakonia Dan Diakonat Gereja. Jakarta: BPK Gunung Mulia, 2010.

. Unsur-Unsur Liturgi Yang Dipakai Oleh Gereja Di Indonesia. Jakarta: BPK Gunung Mulia, 2007.

Alkitab Sabda. “Diaken .” Sabda. Last modified 2019. Accessed May 14, 2020. https://alkitab.sabda.org/dictionary.php?word=Diaken.

Avila, Mariano, and Esko Ryökäs. "The The Church as Diaconia. One View of the Reformed Understanding of Diaconia." Diakonian tutkimus, no. 1S (May 12, 2020). Accessed August 11, 2020. https://journal.fi/dt.

Budiman, R. Tafsiran Alkitab: Surat-Surat Pastoral I \& II Timotius Dan Titus. Jakarta: BPK Gunung Mulia, 2008.

Febriana, Mariani. "Pietas Dan Caritas: Pelayanan Diakonia Sebagai Suatu Implementasi Kepedulian Sosial Gereja Untuk Menolong Meretas Angka Kemiskinan Di Indonesia." Jurnal Theologi Aletheia 16, no. 7 (2014): 45-69.

Fee, Gordon D. New International Biblical Commentary 1 and 2 Timothy, Titus. United States of America: Hendrickson Publishers, 1988.

Ferrari, Joseph, and Danielle Vaclavik. "The Leadership Style of Permanent Deacons: Servant and Transformational Middle-Aged Ministers." North American Journal of Psychology 18 (2016): 1-16.

Gidion, Gidion. "Memahami Pekerjaan Roh Kudus dalam Pelayanan Gereja Berdasarkan 1 dan 2 Timotius." HARVESTER: Jurnal Teologi dan Kepemimpinan Kristen 4.2 (2019): 108-121

Handayani, Dessy. "Isu-Isu Kontemporer Dalam Jabatan Gerejawi." Kurios 3, no. 1 (February 11, 2018): 66. Accessed November 24, 2020. http://www.sttpb.ac.id/e-journal/index.php/kurios.

Jonch, Christian. "Yesus Sebagai Guru : Studi Injil Yohanes." Veritas : Jurnal Teologi dan Pelayanan 8, no. 2 (October 1, 2007): 257-276. Accessed July 2, 2020. https://ojs.seabs.ac.id/index.php/Veritas/article/view/190.

Jonge, Christiaan de. Apa Itu Calvinisme? Jakarta: BPK Gunung Mulia, 2008.

Leigh, Ronald W. Melayani Dengan Efektif: 34 Prinsip Pelayanan Bagi Pendeta Dan Kaum Awam. Jakarta: BPK Gunung Mulia, 2007.

Majelis Sinode GMIT. "Peraturan Pemilihan Penatua, Diaken, Pengajar Dan Pengesahan Anggota Majelis Jemaat.” Sinode GMIT. Last modified February 2018. Accessed May 16, 2020. https://sinodegmit.or.id.

NETBible. “1 Timotius 3:8-13.” Alkitab Sabda. Last modified 2020. Accessed May 20, 2020. https://alkitab.sabda.org/bible.php?book=54\&chapter=3\&tab=alt\#n14.

Noordegraaf, A. Orientasi Diakonia Gereja: Teologi Dalam Perspektif Reformasi. Jakarta: BPK Gunung Mulia, 2004.

Piliang, Yasraf Amir. "Semiotika Teks: Sebuah Pendekatan Analisis Teks." MediaTor 5, no. 2 (2004): 189.

Prodjowijono, Suharto. Manajemen Gereja: Sebuah Alternatif. Jakarta: BPK Gunung Mulia, 2008.

Putra, R. Masri Sareb. "Tradisi Hermeneutika Dan Penerapannya Dalam Studi Komunikasi." Jurnal ULTIMA Comm 4, no. 1 (June 1, 2012): 73-85. Accessed November 13, 2020. http://ejournals.umn.ac.id/index.php/FIKOM/article/view/431.

Sembiring, Jonatha Freshly. "Gereja Dan Diakonia." Jurnal Teologi Pondok Daud 6, no. 1 (March 3, 2020): 35-42. Accessed November 24, 2020. http://ejournal.sttpkmedan.ac.id/index.php/pondokdaud/article/view/7.

Sinode GMIT. "Diaken Masih Belum Melaksanakan Tugasnya." Sinode GMIT. Last modified December 2016. Accessed May 14, 2020. https://sinodegmit.or.id/diaken-masih-belummelaksanakan-tugasnya-ss-gmit-xxxiii/.

- Peraturan Pemilihan Penatua, Diaken, Pengajar Dan Pengesahan Anggota Majelis Jemaat. Kupang, February 2018.

Sitompul, A.A; Ulrich Beyer. Metode Penafsiran Alkitab. Jakarta: BPK Gunung Mulia, 2009.

Strauch, Alexander. Paul"s Vision for the Deacons: Assisting the Elders with the Care of God's Church. United Sates of America: Lewis \& Roth Publishers, 2017. 
Swindoll, Charles R. Swindoll's Living Insights New Testament Commentary: 1 \& 2 Timoty, Titus. United States of America: Zondervan, 2019.

Timothy. "The Meaning Of 'The Husband Of One Wife' In 1 Timothy 3:2,” 2007.

Utley, Bob. Perjalanan Penginjilan Paulus Ke-4: I Timotius, Titus Dan II Timotius. Marshall, Texas: Bible Lesson International, 2013.

Westa Purba, Deora. "Hermeneutika Sebagai Metode Pendekatan Dalam Teologi." Regula Fidei 3, no. 1 (March 2018): 520-530. Accessed November 12, 2020.

http://ejournal.uki.ac.id/index.php/regulafidei/article/view/978.

Zehr, Paul M. Believers Church Bible Commentary: 1 \& 2 Timothy, Titus. Canada: Herald Press, 2010. 